\title{
Heritage interpretation through an architectural design
}

\author{
Bartosz Marek Walczak ${ }^{1, *}$ \\ ${ }^{1}$ Lodz University of Technology, Institute of Architecture and Urban Planning, Department of Heritage \\ Conservation, Revitalisation and History of Architecture, al. Politechniki 6, 90-924 Lodz, Poland
}

\begin{abstract}
The paper presents results of a heritage conservation studio at the Institute of Architecture and Urban Planning, Lodz University of Technology. Students were challenged to propose an architectural intervention aiming at storytelling of the palimpsestic past, as well as upkeeping the unique ambiance of the place. Furthermore, students were encouraged to play with the use of the building and perception of the site. Submitted projects allowed to make a number of interesting observations.
\end{abstract}

\section{Introduction and background}

The paper presents results of a heritage conservation studio at the Institute of Architecture and Urban Planning, Lodz University of Technology. Participating students were challenged to propose an architectural intervention at the site with a rich history.

This place already in Medieval times was used as a location of a water powered flour mill (recorded for the first time in the late $14^{\text {th }}$ century). This was the property of the church leased to mayors of Łódź, which was reflected by the name of this site: Wójtowski Młyn. The whole area was not subject to investment and development until late $18^{\text {th }}$ century, when all church properties - including this one - were secularised. This opened new perspectives. In the early $19^{\text {th }}$ century, by means of governmental decision, the town of Łódź and nearby villages were designated as a major textile centre production. Among the reasons there were ample water resources and well-developed milling infrastructure [1], which could be easily transformed to the needs of new textile factories.

The site was acquired by Christian Friedrich Wendisch - one of the Saxon entrepreneurs invited to Łódź to establish industrial production. As a consequence, in 1824, the existing all-timber structure was adjoined by the very first purposely-built cotton-spinning mill in Łódź. The location of a water wheel lade was adopted. The new industrial building was timber-framed, on the masonry basement walls, according to its description and measured drawings hold in the archives [2] (fig. 1.). The enterprise was thriving over a very short time. The factory master died unexpectedly in 1830 and the building itself remained abandoned for several years. The mill was re-opened and enlarged by the new owner - Friedrich Moes.

* Corresponding author: bartosz.walczak@p.lodz.pl 
Production continued until 1863, when the factory was badly damaged by a fire. Finally, the site was overtaken by another successful industrialist - Karl Scheibler - who transformed this area into a farm providing food for his workforce and some organic components necessary for dyeing and fixing processes. The foundation walls of previously existing building ware used to build a house for a manager of the farm (fig. 1.). The building survived until present time. However, its uses changed several times and the structure was adjusted to the subsequent needs such as car repair workshop. Finally, in 2002 it was given to a local scout team as storage for boats and yachts.
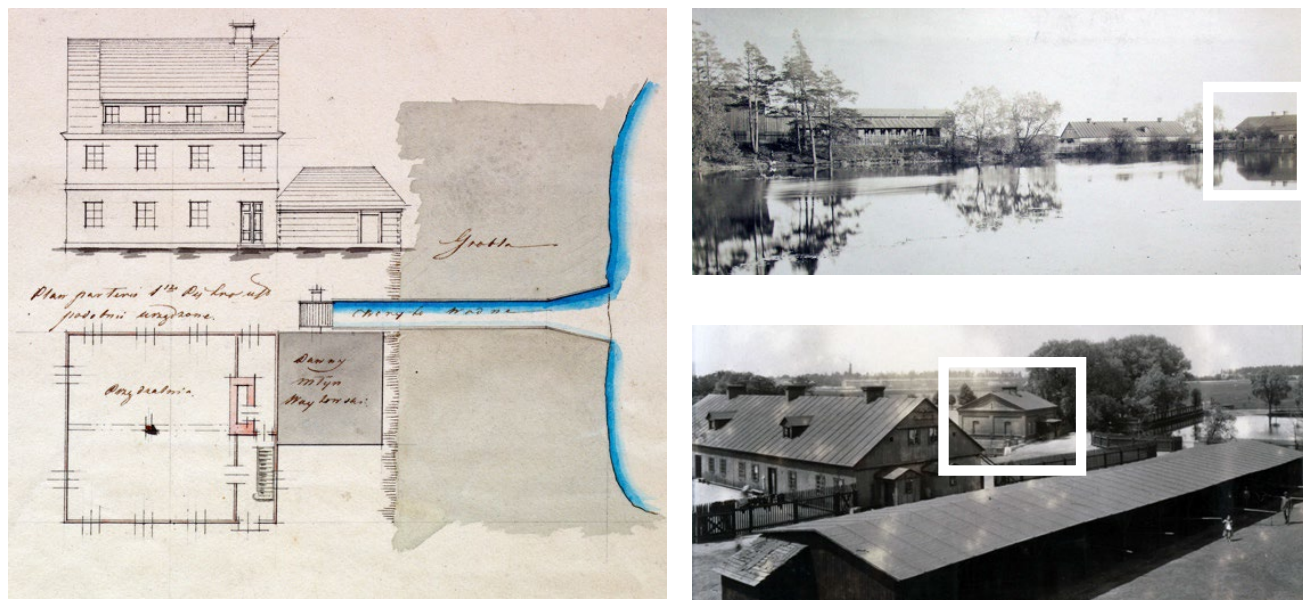

Fig. 1. Archival records of the buildings on the site in question: The Wendisch spinning mill with adjoining old mill (left); images of the Scheibler farm in the 1880s with existing building framed in white (right). Sources: State Archives in Warsaw; Central Museum of Textiles in Lodz.

In 2008, the site drew attention of Zbigniew Rybacki, a local archaeologist. With the support from the state heritage conservation office in Łódź, archaeological research was launched and continued until 2011. The excavations proved to be a valuable source of information on the site history and its palimpsestic nature. First, the exact location of the very first mill was identified. Unfortunately, only a ground beam and couple of boards were excavated. It was, however, enough to recognise a structural type as "post and plank" and indicate the time-frame of its construction as the $16^{\text {th }}$ century. The shape, volume and appearance had to remain unknown (fig. 2.). 

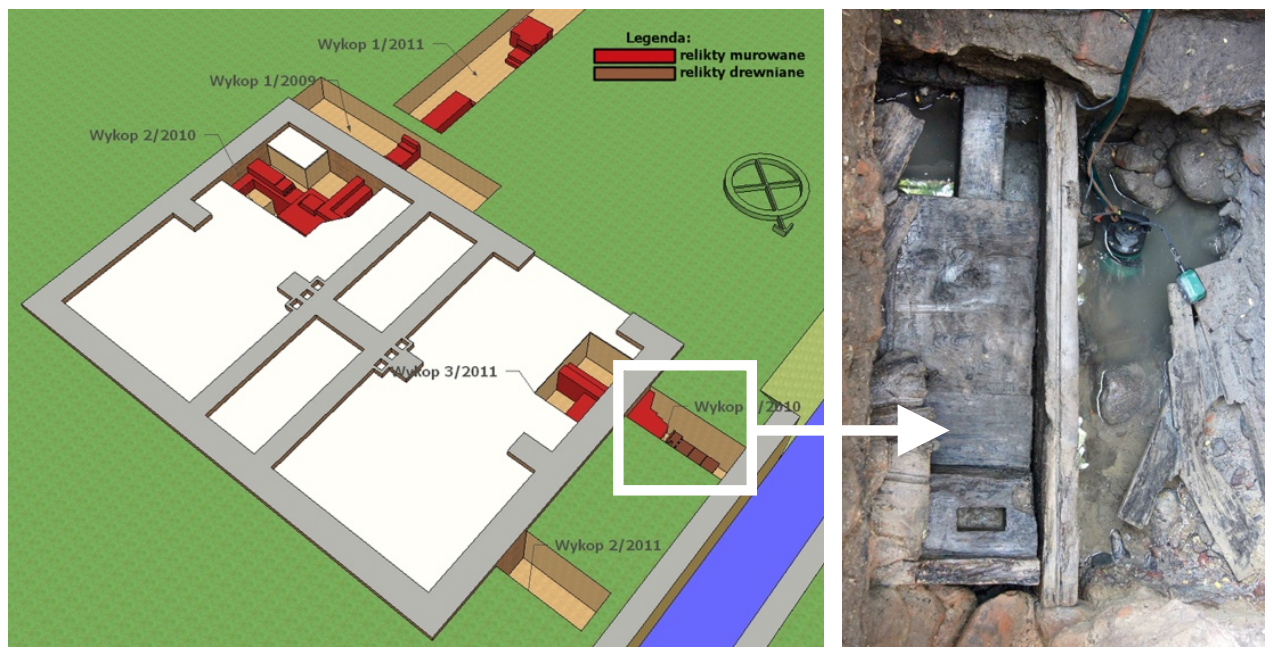

Fig. 2. Archaeological research report. 3D representation of excavations (left) and relics of the old water mill (right). Sources: image and photo provided by Zbigniew Rybacki and Maciej Milczarek.

Furthermore, the location of the Wendisch mill of the 1820 s was proved. Additional investigations of the existing building walls allowed to identify relics of the Moes mill. As a result, it was possible to reconstruct the history of the site and locate all the stages of its development. In order to communicate the research outcomes, the team of archaeologists invited experts in virtual reality. Unfortunately, the proposed visualisations left no place for further interpretation, as they were so obvious and complete, even there had been not enough evidence. But it did not prevent the visualisation team from proposing the full reconstruction of a mill and of other associated buildings of which we know nothing (fig. 3.). The result is in strong opposition to the requirement of the London Charter [3], an important document, based on the longstanding (and still ongoing) debate on how to transmit knowledge to a larger audience and to avoid any misleading of members of the public. Sadly, authors of the VR reconstruction were, most likely, not aware of this Charter existence. Fortunately, the virtual reconstruction was shown only during a few presentations of the archaeological research on a forum of local history association. For most of the local society, the site remains just another uninteresting old building, like many similar sites in the city.
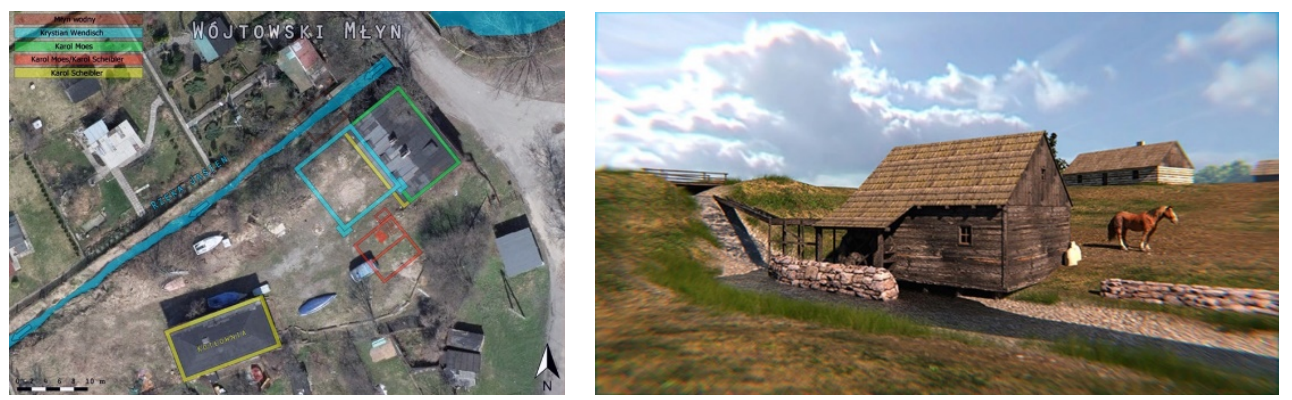

Fig. 3. Archaeological research report. Stages of building development (left); virtual reconstruction of the old water mill (right). Sources: images provided by Zbigniew Rybacki and Maciej Milczarek. 


\section{Project description}

Without doubts, there is a discrepancy between the rich historic content of the site and its current condition. Despite being used by scouts, the building is semi-derelict, and entrance to the site is concealed due to open-air storage of the boats. Only a small board on the front façade provides basic information on the site history. But it is not enough to make an effort to visit the site. Picturesque location on a former mill pond, on opposite site of which, there is a public park on the edge of a large housing estate, which seems, however, to create some opportunities (fig. 4.). But apparently, the use and the appearance have to be improved significantly to attract local community and other city dwellers.
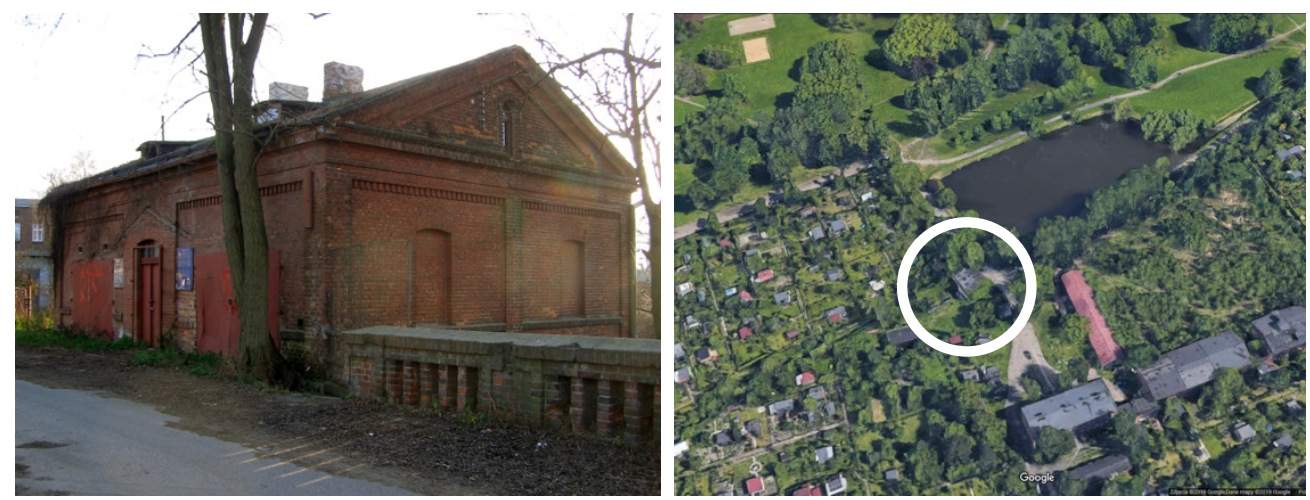

Fig. 4. Existing building - former farm manager's house (left); site in the context of allotments and parklands (right). Sources: photo by Filip Tomaszewski; Google Maps.

This situation inspired the author to conduct an experiment with a group of master-degree students. The project was expected to take 7-8 weeks (half a semester). At the beginning, students were given initial information on the history of the site. The package included a map, measured drawings of the building, copies of archival documents and images, and other secondary resources. Then, the site visit was arranged. Students could see the building and meet the scout leader who reported major maintenance problems. This was enhanced with a lecture by Mr. Zbigniew Rybacki - the archaeologist responsible for the mill excavations. On this basis, students were to analyse the site and its context and to formulate their own design guidelines/principles. On this basis, they were challenged to propose an architectural intervention aiming at:

- storytelling of the palimpsestic past, including different strategies matching the variable knowledge (and even lack of knowledge) on particular stages of the site development;

- upkeeping the unique ambiance - feeling of being in a remote agricultural location, while the site just outside the city centre;

- adoption of matching building materials;

- proposing a new use attracting members of contemporary society.

In other words, the project was expected to investigate opportunities of providing real architecture instead of virtual reconstruction to make the site more meaningful [4]. This means that storytelling has to be embedded - to some extent - in the proposed architectural interventions. Furthermore, students were encouraged to play with the use of the building and perception of the site. Thus, locality was expected to become another important strategy in the designing process.

The new use was to be decided by students. They were, however, informed that the site would be considered as one of the pilot projects related to the EXPO Horticultural, which would be organised in Łódź in 2024 [5]. 


\section{Project outcomes}

It is necessary to stress that the project was preceded by another task, aiming at the commemoration of a protestant church destroyed during World War II. The students gained, therefore, some experience in heritage interpretation. They learned how to tackle ruins and erect new structures above/aside. The studio was accompanied by a series of lectures on heritage conservation theory and good practices in this domain. The students formed twoperson teams. More than 30 designs were submitted as a result of this project. This was an ample material to make some interesting observations in respect of the heritage interpretation by means of architectural solutions.

A large group of students focused on the oldest structure - viz. the water-powered flour mill. Łódź, as a city has Medieval origins, but its actual development took place throughout the $19^{\text {th }}$ century. Therefore, the existence of a structure older than 200 years was apparently inspirational. Since there was not enough information on the mill appearance, many students decided to manifest its existence and primary use in the most obvious way - by using a waterwheel as an icon. Some of them tried to play also with a platform (usually made of wooden boards) depicting the building location and outline. Surprisingly, the most of such proposals disregarded presence of running water and - as a result - these wheels remained merely static sculptures - conceived as either free-standing objects or incorporated in a new structure (fig. 5.).

In this respect, it is necessary to mention one proposal, which included a "reconstruction" of the mill. Unexpectedly, authors of this design decided to follow the VR presentation ordered by archaeologists, even all its drawbacks had been underlined during the introductory lecture. For some reason, the students did not use an outline of the mill seen on the archival document (fig. 1.). Instead, they repeated literally the shape and volume shown in the aforementioned presentation (fig. 6.). Without doubt, this case proves the delusive nature of virtual models and their potential malfunction in the heritage interpretation. It seems that such representations of hypothetical appearance of no longer existing structures have to be less obvious and stimulating imagination of visitors - like, for example, Venturi's famous Benjamin Franklin house in Philadelphia.
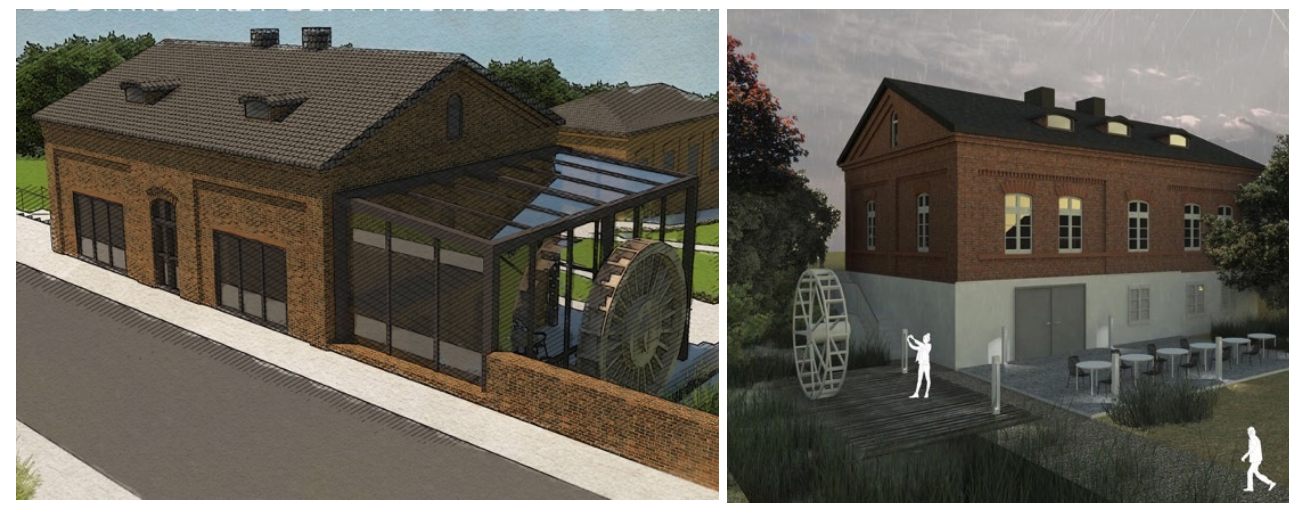

Fig. 5. The waterwheel as a prime source of inspiration for new architectural interventions: a café by Malgorzata Szczesna and Patrycja Wawrzyniak (left) and a sculpture by Marta Canert and Maja Ciszewska (right). Sources: the Department of Heritage Conservation, Revitalisation and History of Architecture, TUL.

The latter idea was successfully deployed by another team of students, who proposed simple, white-painted steel frames. Their geometry and distribution suggest the existence of 
the mill and, what is more interesting, location of other buildings, including the Wendisch factory, so important for the early industrialisation of Łódź. The concept was enhanced by a kinetic installation (a rotating waterwheel linked with cogwheels by a transmission belt) referring to the both stages of site development: milling and spinning (fig. 7.).
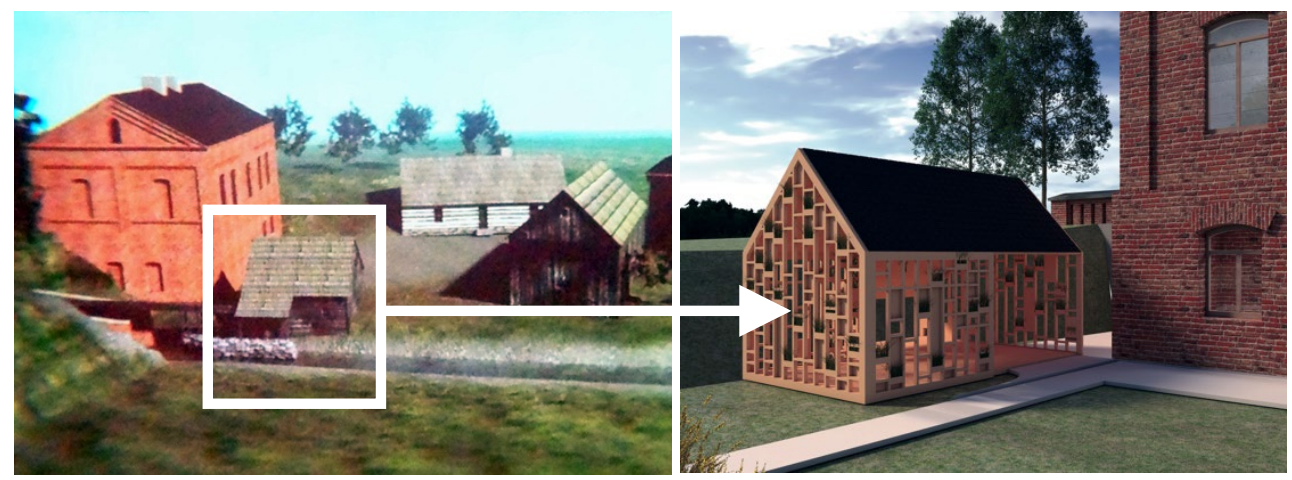

Fig. 6. A small pavilion by Adrian Smigielski and Jakub Wlostek (right) shaped on the basis of the virtual model commissioned by archaeologists (left). Sources: images provided by Zbigniew Rybacki and Maciej Milczarek; the Department of Heritage Conservation, Revitalisation and History of Architecture, TUL.
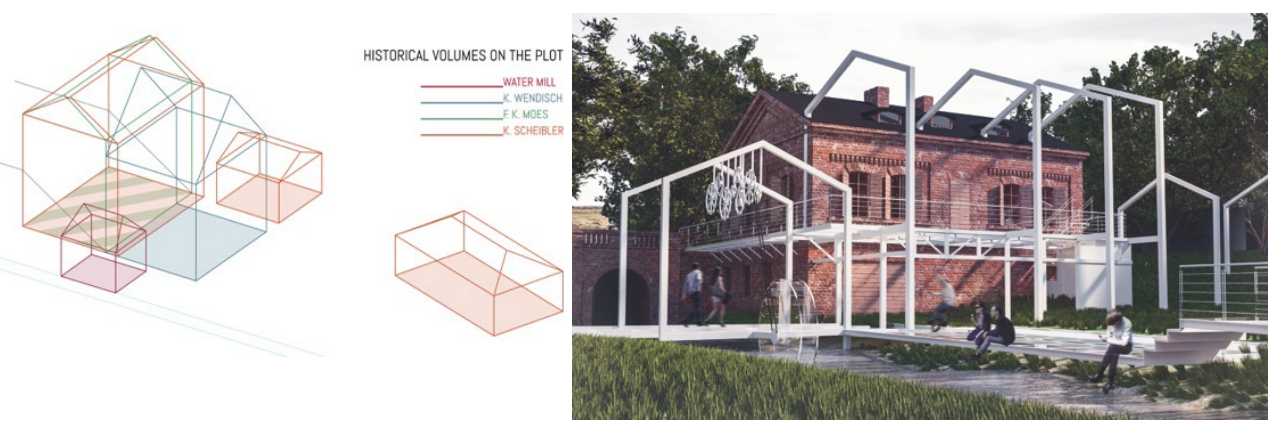

Fig. 7. Three-dimensional representations of palimpsestic past: volumes analysis by Joanna Sobczak and Paula Popczak (left); frames and platforms reflecting no longer existing structures by Patryk Jankowski and Julia Mejer (right). Sources: the Department of Heritage Conservation, Revitalisation and History of Architecture, TUL.

This was not the only design, which explored palimpsestic history through superimposed volumes of buildings existing now and in the past. Some students studied this topic during the analytical stage (fig. 7.), while their creation for some reasons did not reflected the outcomes. Only a few teams decided to take the risk and experiment not only with volumes and shapes but also with textures and materials to make their proposal more meaningful. One of the most comprehensive proposals included a minimalistic platform on the site of the Medieval mill, and a timber-framed pavilion on the site of the Wendisch cotton-spinning factory. The pavilion had glazed curtain walls instead of masonry fillings, while its roof was proposed as a textile membrane. These decisions aimed at the creation of a structure which would be recognised as a contemporary even by laymen. Furthermore, some small additions (like an exhibition of actual archaeological relics) were designed as simple as possible, without any reference to the past. This was, again, underpinned by careful usage of cladding material. Steel mesh was chosen for the purpose. The students also eagerly responded to the 
idea of EXPO Horticultural. They proposed to transform surrounding allotments into vineyards and the mill site into a winery. Their idea was to draw attention of visitors to climate change, allowing successful winemaking in such unexpected location (fig. 8).
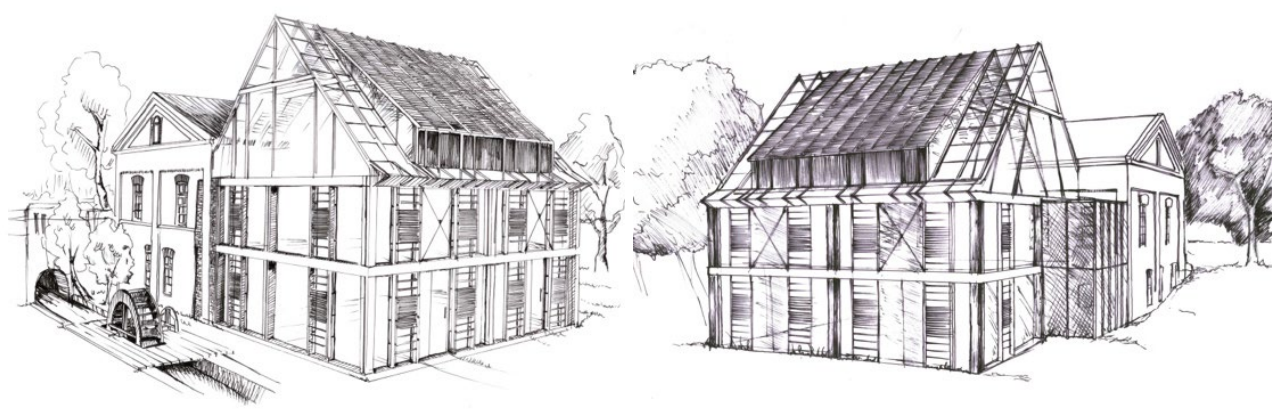

Fig. 8. The comprehensive approach to the issue of the past: a winery by Piotr Mrowczynski and Anna Rawa. Sources: the Department of Heritage Conservation, Revitalisation and History of Architecture, TUL.

Apart from storytelling, students attending the studio were encouraged to focus on the particular atmosphere of the site. In this respect, a self-restriction proved to be the most fruitful design strategy. There were several proposals using very modest means to represent history of the site in order to upkeep peaceful ambiance of the area. Simple decking, pathways, and greenery matched a semi-agricultural appearance of the neighbourhood. Also proposed new uses reflected this unique location: the building could serve as a community centre with a charming outdoor dancing area, workshop area, or significantly improved scouts meeting place (fig. 9.).

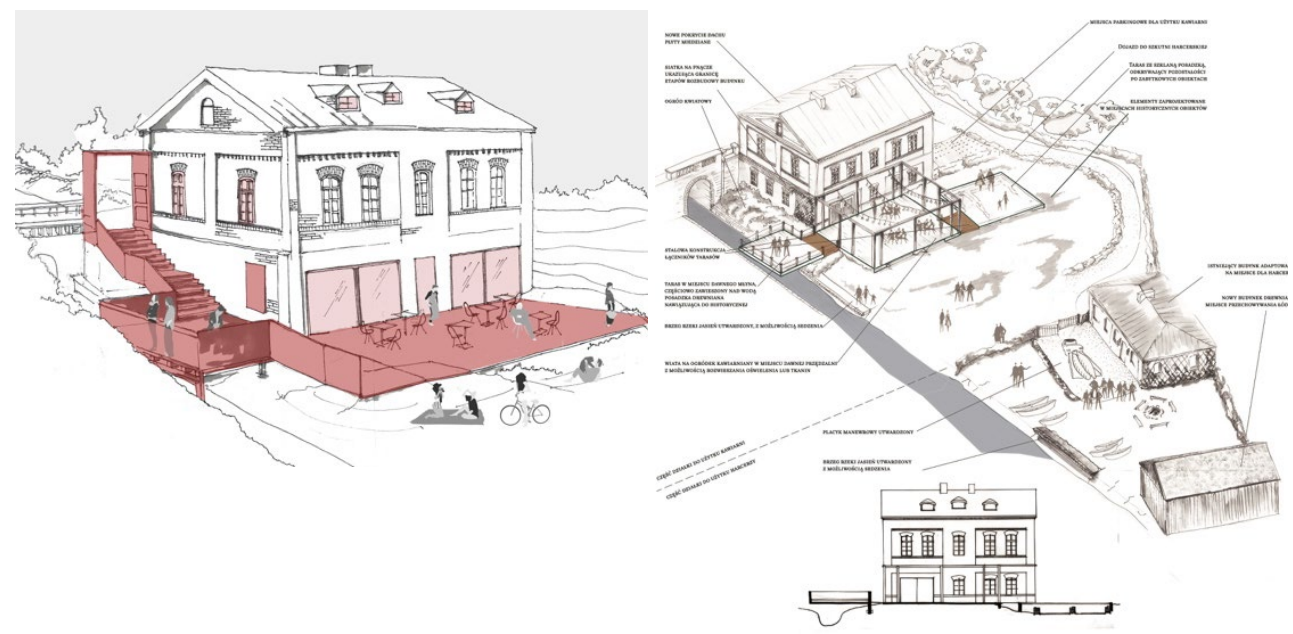

Fig. 9. Simplicity and self-restriction as a design strategy: by Patrycja Stelmach and Marta Zielinska (left); by Anna Helena Sluzewska and Justyna Zareba (right). Sources: the Department of Heritage Conservation, Revitalisation and History of Architecture, TUL.

It is impossible not to mention intangible factors affecting perception of the site when the ambiance issues are being discussed. The students usually properly recognised the value of peaceful location in the middle of the large city. Some of them - as was mentioned above - 
tried to upkeep this ambiance. Very few, however, made a step further and tried to represent the site in a sensitive way. Proposed visualisations were typically focused on shapes and volumes of buildings. Lightning conditions, colours of the sky, greenery varied significantly and were far from the reality. Even when the effort to create particular nostalgic atmosphere was made, the result was rather disappointing (fig. 10.). Ironically, those teams, who used analogue methods of representation achieved better results in this respect. Previous experiments and research conducted by author proved however that students would be capable of proper representing the "genius loci" of the place when instructed properly [6]. Yet, the representation issues were beyond the scope of the heritage conservation studio.

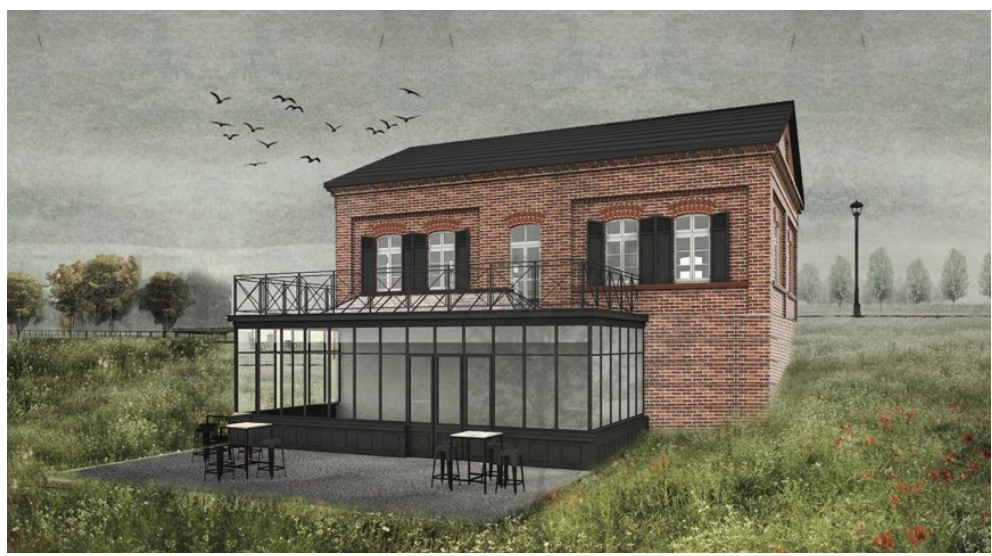

Fig. 10. Atmospheric vision created by Aleksandra Durak and Katarzyna Gulink - nostalgic but far from the reality. Sources: the Department of Heritage Conservation, Revitalisation and History of Architecture, TUL.

\section{Conclusions}

Tutors and students alike were attracted by the topic of the described heritage conservation studio. Academics underlined that the Wójtowski Młyn site had a good size, possible to analyse in a limited time frame and offered a number of heritage issues to be tackled. Students' feedback revealed that this was something new and therefore interesting. Some of them indicated also that from one hand they enjoyed experimenting but from another they had not enough confidence/knowledge/experience to understand the limits of acceptable intervention. Even so, most of the submitted proposals were of high quality and the studio goals were achieved to a large extent :

- Architectural solutions proved to be an effective tool for the storytelling of the palimpsestic past, but only the minority of participating students exploited the full potential of shapes, volumes and materials to make place more meaningful; it is also significant that, apart from the waterwheel, technology was a disregarded part of heritage, which is however problematic worldwide as recent research revealed [7].

- The task of upkeeping the unique ambiance was approached in a less successful manner - feeling of being in a remote agricultural location, while the site just outside the city centre was properly identified, but most of students did not include it in their design strategies; only a few proposal revealed a proper sensitivity to the ambiance of the neighbourhood both in terms of design and representation.

- The adoption of matching building materials appeared challenging for many students; probably they are not enough knowledgeable in this matter, which is surprising since 
usually they used to be familiar with works of Peter Zumthor as well as his writings [8]; nevertheless, a particular attention should be paid in the future to draw their attention to opportunities offered by various materials in terms of texture, feeling, etc.

Despite some reservations and minor mistakes, the outcome of the heritage conservation studio may become valuable material for a discussion on the future of the site. Some ideas will be presented to the city officials responsible for the EXPO Horticultural along with some recommendation on possible scenarios of re-using the site in a manner matching its importance for the local heritage.

\section{Acknowledgements}

Author would like to thank all the individuals involved in the Wójtowski Młyn project: Dr. Magdalena Bednarkiewicz, Dr. Maria Dankowska, Prof. Jan Salm, and Mr. Filip Tomaszewski who were tutoring students; Mr. Zbigniew Rybacki who provided the results of archaeological investigations; Mrs. Joanna Filipiak-Markiewicz who allowed access to the site.

\section{References}

1. A. Bartnik, D. Bartnik, Rozmieszczenie młynów wodnych na obszarze Łodzi w świetle wykorzystanych historycznych źródeł kartograficznych, Z Dziejów Kartografii, XXI, 1140 (2017)

2. The Central Archives of Historical Records in Warsaw, AGAD PL 1402 30-4 003

3. http://www.londoncharter.org/ access: 19.10.2018

4. UCL, Making spaces meaningful through architectural storytelling (2017)

5. https://expo2024.uml.lodz.pl/en/ access: 04.02.2019

6. A. Kepczynska-Walczak, B.M. Walczak, Built heritage perception through representation of its atmosphere, Ambiances Review (2015)

7. J. Douet (ed.), Industrial Heritage Re-tooled: The TICCIH Guide to Industrial Heritage Conservation (2013)

8. P. Zumthor, Thinking architecture (1998) 